\title{
EVALUASI UJI KOMPETENSI SISWA KEAHLIAN MULTIMEDIA DI SMK SE-KOTA YOGYAKARTA
}

\author{
Yowanita Dwi Irwanti \\ Pendidikan Teknologi dan Kejuruan Program Pascasarjana UNY \\ aisyputh@yahoo.com \\ Putu Sudira \\ Universitas Negeri Yogyakarta \\ putupanji@uny.ac.id
}

\begin{abstract}
Abstrak
Penelitian ini bertujuan untuk mengevaluasi uji kompetensi siswa keahlian multimedia di SMK SeKota Yogyakarta, ditinjau dari aspek: (1) context; (2) input; (3) process; (4) product; dan (5) CIPP secara akumulatif. Penelitian ini dilaksanakan pada delapan SMK di kota Yogyakarta. Populasi adalah asesor, yang berjumlah 44 orang. Sampel dengan sampel jenuh (total). Teknik pengumpulan data menggunakan angket. Uji validitas dengan validitas isi melalui expert judgement, validitas konstruk dengan uji terbatas, dan dianalisis dengan korelasi Product Moment. Uji reliabilitas menggunakan Alpha Cronbach. Teknik analisis data dengan analisis deskriptif. Hasil penelitian ini menunjukkan bahwa uji kompetensi siswa keahlian multimedia di SMK Se-Kota Yogyakarta ditinjau dari aspek: (1) context termasuk kategori sangat sesuai (84,7\%); (2) input termasuk dalam kategori sangat sesuai (87,61\%); (3) process termasuk kategori sangat baik (89,94\%); (4) product termasuk kategori sangat baik (82,78\%); (5) CIPP secara akumulatif termasuk kategori sangat baik (86,62\%).
\end{abstract}

Kata Kunci: evaluasi, CIPP, uji kompetensi, multimedia

\section{EVALUATION OF MULTIMEDIA SKILLS STUDENTS COMPETENCY TEST IN SMK YOGYAKARTA}

\begin{abstract}
This study aims to evaluate the multimedia skills students competency test in SMK Yogyakarta, in terms of (1) aspects of the context; (2) the input; (3) the process; (4) the product; and (5) CIPP aspects cumulatively. This study was conducted at eight vocational schools in the city of Yogyakarta. The population was assessors, amounting to 44 people. The sample used saturated or total sample. Data collection techniques used questionnaires. Test validity of the content validity is expert judgment and construct validity with product moment correlation formula. Test reliability was carried out with Alpha Cronbach. The data analysis technique used is descriptive analysis. The results of the study show that the multimedia skills students competency test in SMK Yogyakarta in terms of (1) aspects of the context fall into the very appropriate category (84.7\%); (2) the input are in the very appropriate category (87.61\%); (3) the process are the excellent category (89.94\%); (4) the product are the excellent category (82.78\%); (5) aspects of CIPP cumulatively are the excellent category $(86.62 \%)$.
\end{abstract}

Keywords: evaluation, CIPP, competency testing, multimedia 


\section{PENDAHULUAN}

Dalam penjelasan Undang-Undang Nomor 20 Tahun 2003 tentang Sistem Pendidikan Nasional disebutkan bahwa pendidikan kejuruan merupakan pendidikan yang mempersiapkan peserta didik untuk bekerja dalam bidang tertentu. Wardiman D. (1998, p.36) mendeskripsikan pendapat Rupert Evans bahwa pendidikan kejuruan adalah pendidikan yang bertujuan untuk: (1) memenuhi kebutuhan masyarakat akan tenaga kerja; (2) meningkatkan pilihan pendidikan bagi setiap individu; dan (3) menumbuhkan motivasi untuk belajar sepanjang hayat. Menurut Good dan Harris dalam Sudira (2012, p.12) mendefinisikan "vocational education is education for work-any kind of work which the individual finds congenial and for which society has need". Pendidikan vokasi adalah pendidikan untuk bekerja dimana seseorang mendapatkan pekerjaan yang menyenangkan atau cocok seperti harapan masyarakat pada umumnya. Agar bisa mendapatkan pekerjaan yang cocok maka masyarakat pengguna pendidikan kejuruan harus mengerti dan memahami dengan baik jenis-jenis lapangan kerja dan berbagai jenis bidang keahlian yang di selenggarakan di SMK.

Untuk mencapai tujuan pendidikan kejuruan tersebut, maka penyelenggaraan pendidikan kejuruan tidak dapat dipisahkan dari dunia industri sebagai institusi penyerap tenaga kerja. Oleh karena itu, pendidikan kejuruan harus didesain agar para lulusan dapat mengembangkan keterampilan, kemampuan, pengetahuan, sikap dan kebiasaan kerja yang diperlukan untuk memasuki dunia kerja.

Dalam pendidikan kejuruan, SMK merupakan pendidikan pada jenjang menengah yang mempersiapkan dan mengembangkan kompetensi siswa untuk memasuki dunia kerja, sehinggan kualifikasi lulusan SMK juga harus sesuai dengan kebutuhan dunia usaha dan industri. Kompetensi keahlian Multimedia merupakan salah satu kompetensi keahlian di bidang studi keahlian Teknik Komputer dan Informatika. Tujuan kompetensi keahlian Multimedia adalah membekali peserta didik dengan pengetahuan, keteterampilan dan sikap agar kompeten di bidang multimedia. SMK sebagai pendidikan untuk dunia kerja, maka siswa SMK wajib menguasai tuntutan kompetensi keahlian yang dijabarkan dalam Standar Kompetensi Keahlian Multimedia.

Kebutuhan terhadap tenaga terampil dan tenaga ahli di bidang mulitmedia akan terus meningkat. Keahlian di bidang multimedia semakin dibutuhkan dalam aktivitas sehari-hari, baik di dunia kerja atau di dunia industri. Pekerjaan di bidang multimedia sangat banyak dan beragam sesuai dengan namanya. Ruang lingkup pekerjaan bagi lulusan Kompetensi Keahlian Multimedia adalah jenis pekerjaan dan atau profesi yang relevan dengan kompetensi yang sesuai dengan SKKNI Bidang Teknologi Infomatika pada jenjang SMK.

Dalam konteks pendidikan, asesmen atau penilaian merupakan suatu kegiatan untuk mengetahui perkembangan, kemajuan dan hasil belajar siswa. Menurut Wagiran (2011) bahwa penilaian merupakan upaya sistematis yang dikembangkan oleh suatu institusi pendidikan yang ditujukan untuk menjamin tercapainya kualitas proses pendidikan serta kualitas kemampuan peserta didik sesuai dengan tujuan yang telah ditetapkan (Aiken, 1985, Anastasi, 1988, Buckendahl, 2002, Cullen, 2003). Hasil dari penilaian tersebut kemudian digunakan sebagai dasar untuk melakukan tindakan dalam mengambil keputusan tentang pengetahuan, sikap, dan keterampilan siswa. Penilaian hasil belajar pada Sekolah Menengah Kejuruan, selain dilakukan oleh pendidik, satuan pendidikan, dan pemerintah juga oleh masyarakat (DU/DI). Penilaian oleh pendidik dan satuan pendidikan merupakan penilaian internal (internal assessment) dalam rangka penjaminan mutu, sedangkan penilaian oleh pemerintah dan masyarakat (DU/DI) merupakan penilaian eksternal (external assessment) sebagai pengendali mutu.

Kurikulum Tingkat Satuan Pendidikan yang berbasis kompetensi menuntut model dan teknik penilaian yang dilakukan secara internal dan eksternal sehingga dapat diketahui perkembangan dan ketercapaian berbagai kompetensi peserta didik.

Penilaian hasil belajar siswa SMK dalam hal ini uji kompetensi keahlian siswa termasuk pada penilaian berbasis kompetensi (Competency based Assessment) yaitu penilaian 
yang dilakukan untuk menentukan peserta didik sudah kompeten atau belum. Karena uji kompetensi keahlian bertujuan untuk dapat mengetahui ketercapaian kompetensi peserta didik pada akhir periode maka penilaiannya termasuk pada jenis penilaian sumatif yakni penilaian hasil belajar untuk menentukan pencapaian akhir dari pembelajaran.

Kompetensi yang diukur dan dinilai yaitu mengenai performansi siswa meliputi aspek pengetahuan, keterampilan, dan sikap. Dalam konteks pendidikan kejuruan kompetensi berfokus pada kemampuan individu dalam melakukan tugas tertentu. Hal ini seperti yang dikemukakan oleh Bernd Haasler dan John Erpenbeck dalam Rauner, F. \& Maclean, R (2008, p.766) bahwa: "...competence in the context of vocational education research, which focuses on individual skills and competencies needed to master the job tasks proficiently and independently." Dapat dijelaskan bahwa kompetensi dalam konteks pendidikan vokasional, yaitu berfokus pada kemampuan individu dan kompetensi yang diperlukan untuk menguasai tugas pekerjaan secara mahir dan mandiri.

Menurut Gangani (2006, p.136) kompetensi dalam dunia kerja dapat dijabarkan kedalam tiga kelompok besar: pertama, kompetensi dasar (fundamental competencies) yaitu kompetensi yang harus dimiliki oleh semua pekerja lintas bidang. Kedua, kompetensi fungsional (funcional competencies) yaitu kompetensi yang mengantarkan seorang pekerja mampu melaksanakan tugasnya sekarang dengan efektif. Ketiga, kompetensi personal (personal competencies) yaitu kompetensi yang mendukung pencapaian tujuan individual dan mempersiapkan dirinya mencapai level pekerjaan yang lebih tinggi atau masa depan.

Dalam konteks dunia industri kualitas tenaga kerja bergantung pada kualitas sistem yang dimiliki seseorang dengan keterampilan yang pantas, kebiasaan (habits), dan sikap dalam setiap langkah kehidupannya sebelum memasuki dunia kerja, selama dalam pekerjaan, dan diantara pekerjaan dan karier (Stern, 2003). Selama proses persiapan karier pertamatama sangat perlu memperhatikan fundamental skills yang terdiri dari basic skills (listening, reading, writing, speaking, math), thinking skills (how to learn, create, solve problem, make decision,ect), dan personal qualities (Responsibility, integrity, self-confidence, moral, character,loyality, etc). Fundamental skills sangat penting dan pokok dalam perkembangan karier seseorang dalam pekerjaan. Di atas fundamental skills ada generic work skills, industry-specific skills, dan company/employer specific skills seperti Gambar 1.

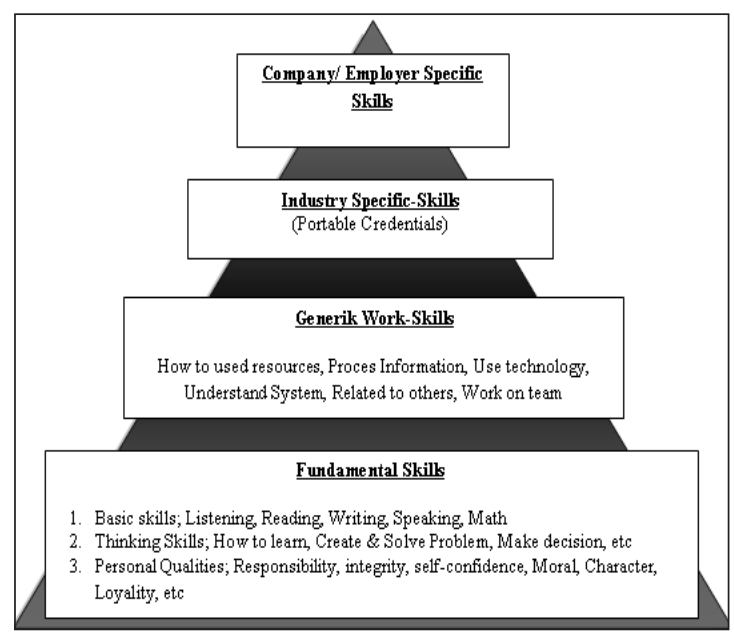

Gambar 1. Struktur Skill Pendidikan \& Pelatihan untuk Kerja (Stern, 2003)

Kompetensi berfokus pada kemampuan individu untuk menguasai tugas atau pekerjaan dengan sebaik-baiknya. Kemampuan seseorang tersebut mencakup atas pengetahuan, keterampilan dan sikap yang direfleksikan dalam kebiasaan berpikir dan bertindak secara konsisten dan terus menerus untuk melakukan suatu pekerjaan tertentu secara profesional. Seseorang dikatakan memiliki kompetensi (berkompeten) dalam bidang tertentu, manakala ia dengan segenap pengetahuan, keterampilan dan sikap untuk menyelesaikan tugas/ pekerjaan tersebut dengan baik sesuai dengan tuntutan profesionalisme.

Uji kompetensi diperlukan untuk mengetahui kemampuan atau keahlian (kompetensi) seseorang sesuai dengan standar profesi. Untuk dapat diterima bekerja di dunia kerja seseorang harus kompeten yang antara lain dibuktikan dengan sertifikat kompetensi melalui uji kompetensi. Colardyn dalam Maclean (2009, p. 2780) menjelaskan bahwa

...recognition of competences often translates into the 'certification' of small units 
or modules. Too rarely have these competencies been fully recognized by employers and enterprises with regard to concrete decisions about hiring, salary and promotion. Sertifikasi merupakan pengakuan kompetensi. Kompetensi ini telah sepenuhnya diakui oleh perusahaan dan berkaitan dengan keputusan mengenai perekrutan, gaji dan promosi.

Uji kompetensi bertujuan untuk memastikan indikator-indikator kompetensi siswa terpenuhi dan dapat dikembangkan lebih lanjut. Menurut UNESCO (2003, p.128) uji kompetensi dimaksudkan untuk menilai keterampilan kerja. Menurut Berry (1979, pp.169-170) bahwa tujuan Ujian Nasional ialah mendorong siswa bercita-cita untuk prestasi akademik yang lebih tinggi dan sebagai sarana untuk menilai apakah sekolah telah melalakukan tugasnya dalam mendidik siswa. Berdasarkan Petunjuk Teknis (Juknis) penyelenggaraan ujian nasional SMK (2013) tujuan UN adalah untuk menilai pencapaian kompetensi lulusan secara nasional pada mata pelajaran tertentu dalam kelompok mata pelajaran ilmu pengetahuan dan teknologi, dalam rangka pencapaian standar nasional pendidikan.

Dalam pelaksanaan uji kompetensi guru dan DU/DI sangat berperan penting dalam penilaian kompetensi yang dimiliki siswa. Dalam penilaian uji kompetensi guru merupakan asesor internal yang harus memenuhi kriteria yang telah ditetapkan, sedangkan DU/DI berfungsi sebagai eksternal yang harus memenuhi kriteria yang telah ditetapkan dan mempunyai kompetensi sesuai bidang yang diujikan. Uji kompetensi keahlian multimedia di SMKSMK Yogyakarta saat ini telah dilakukan di masing-masing sekolah. Perlu adanya standarisasi uji kompetensi agar sekolah-sekolah menghasilkan lulusan yang memang memiliki kompetensi. Standarisasi kompetensi keahlian di bidang multimedia sedang diupayakan oleh pemerintah, tetapi sejauh mana standarisasi tersebut dijalankan perlu ada kajian lebih dalam.

Hasil dari observasi terhadap pelaksanaan uji kompetensi di lapangan ditemukan bahwa beberapa hal yang yang terkait dengan pelak- sanaan uji kompetensi belum sesuai seperti yang diharapkan dalam pedoman pelaksanaan. Pelaksanaan uji kompetensi keahlian multimedia belum mencerminkan standar kemampuan yang dipersyaratkan dunia kerja. Lulusan SMK belum sepenuhnya memperoleh pengakuan kompetensi kerja melalui pengujian dari lembaga yang berwenang memberikan sertifikasi. Mengingat pentingnya pelaksanaan uji kompetensi siswa untuk mempersiapkan kemampuan atau kompetensi lulusan SMK, maka perlu dilakukan penelitian evaluasi pelaksanaan uji kompetensi.

Weiss (1972, p.4) menyatakan bahwa tujuan evaluasi adalah untuk mengukur dampak atau pengaruh sebuah program dengan membandingkan dengan sasaran atau tujuan program yang telah ditetapkan sebelumnya hasil dari perbandingan akan dijadikan pertimbangan untuk pengambilan keputusan tentang program tersebut untuk peningkatan program dimasa yang akan datang. Demikian juga menurut Fitzpatrick, dkk (2011, p.13) menyebutkan bahwa "purpose of evaluation is to render judgments about the value of whatever is being evaluated". Tujuan evaluasi adalah untuk membuat penilaian tentang nilai apa pun yang sedang dievaluasi. Evaluasi program membantu dalam pembuatan keputusan, meningkatkan program, organisasi, dan masyarakat secara keseluruhan, dan menambah basis pengetahuan.

Ada beberapa hal yang perlu dievaluasi dengan tujuan untuk melihat gambaran pelaksanaan uji kompetensi keahlian multimedia di SMK, baik yang mencakup aspek context, input, process, dan product. Menurut Patton dalam Robinson (2002, p.1) CIPP adalah Programme evaluation is the systematic collection of information abut the activities, characteristics, and outcome of programmes for use by specific people to reduce uncertainties, improve effectiveness, and make decisions with regard to what those programmes are doing and affecting.

CIPP merupakan kumpulan dari informasi yang terangkum secara sistematis mengenai akitivitas, karakteristik dan keluaran dari program yang digunakan oleh orang-orang tertentu. CIPP bertujuan mengevaluasi dan 
mengurangi kegagalan, meningkatkan tingkat efektifitas dan membuat keputusan mengenai program yang akan dilaksanakan beserta dampak yang menyertainya. Tahap model evaluasi CIPP yang dikemukakan Kaufman dan Thomas (2009, pp. 116-117) adalah sebagai berikut: (a) Context Evaluation (Evaluasi konteks) adalah fase awal dalam pengembangan program yang meliputi identifikasi kebutuhan dan desain program. Fase ini juga merupakan upaya untuk menggambarkan dan merinci lingkungan, kebutuhan yang tidak terpenuhi, populasi dan sampel penelitian dan tujuan program. Evaluasi konteks meliputi penggambaran latar belakang program yang dievaluasi, memberikan perkiraan kebutuhan dan tujuan program, menentukan sasaran program dan sejauhmana tawaran ini cukup responsif terhadap kebutuhan yang sudah diidentifikasi; (b) Input Evaluation adalah Evaluasi input digunakan untuk mengidentifikasi apa yang benar-benar diperlukan untuk menetukan definisi tentang tujuan evaluasi yang sedang dilakukan. Masukan (input) merupakan model yang digunakan untuk menentukan bagaimana cara penggunaan sumber daya yang ada bisa mencapai tujuan serta secara essential memberikan informasi tentang apakah perlu mencari bantuan dari pihak lain atau tidak. Aspek input juga membantu menentukan prosedur dan desain untuk mengimplementasi program; (c) Process Evaluation adalah evaluasi proses secara khusus digunakan untuk mendeteksi, mengidentifikasi kekuatan dan kelemahan suatu program yang terjadi selama implementasi suatu program. Evaluasi proses digunakan sebagai rekaman implementasi riil suatu program; dan (d) Product Evaluation Evaluasi produk terjadi ketika suatu program sudah berlangsung dengan penekanan pada pengumpulan informasi yang dibutuhkan untuk suatu keputusan yang dibuat berkenaan dengan suatu program. Evaluasi produk meliputi penentuan (penilaian) dampak umum dan khusus suatu program, mengukur dampak yang terantisipasi, mengidentifikasi dampak yang tidak terantisipasi, memeperkirakan kebaikan program, serta mengukur efektifitas program.

Permasalahan dalam penelitian evaluasi uji kompetensi siswa keahlian multimedia di SMK Se-Kota Yogyakarta meliputi aspek: (1)
Context yaitu kebijakan dan tujuan uji kompetensi kejuruan multimedia, tuntutan pengembangan diri dan peluang lulusan, dan kemajuan IPTEK; (2) Input meliputi kesesuaian kriteria asesor, perangkat, tempat uji kompetensi dan sarana prasarana; (3) Process yang meliputi waktu, prosedur, pengawasan dan sistem penilaian; dan (4) Product meliputi hasil nilai uji kompetensi, produk uji kompetensi dan sertifikat kompetensi. Tujuan dalam penelitian ini yaitu untuk mengetahui uji kompetensi siswa keahlian multimedia di SMK Se-Kota Yogyakarta ditinjau dari aspek: (1) Context; (2) Input; (3) Process; dan (4) Product.

\section{METODE PENELITIAN}

Penelitian ini merupakan penelitian evaluasi (evaluation research) dengan menggunakan model CIPP (Context, Input, Process, and Product). Penelitian ini bersifat deskriptif evaluatif, yaitu penelitian evaluasi yang dilakukan untuk mengetahui nilai variabel mandiri, baik satu variabel atau lebih tanpa membuat perbandingan atau menghubungkan antara variabel satu dengan variabel lain. Penelitian ini difokuskan pada masalah uji kompetensi siswa keahlian multimedia di SMK Se-Kota Yogyakarta.

Penelitian ini dilaksanakan pada 8 (delapan) SMK di kota Yogyakarta yang memiliki kompetensi keahlian multimedia dan telah melaksanakan uji kompetensi siswa keahlian multimedia. SMK Se-Kota Yogyakarta yang dimaksud meliputi: SMK N 2 Yogyakarta, SMK N 3 Yogyakarta, SMK N 7 Yogyakarta, SMK Piri 3 Yogyakarta, SMK Ibu Pawiyatan Tamansiswa Yogyakarta, SMK Muhammadiyah 1 Yogyakarta, SMK Berbudi Yogyakarta, dan SMK Bopkri 1 Yogyakarta. Penelitian dilaksanakan antara bulan Desember 2013 sampai dengan Februari 2014.

Populasi dalam penelitian ini adalah asesor yang terdiri dari guru produktif multimedia dan DU/DI asesor pelaksana uji kompetensi keahlian multimedia di SMK Se-Kota Yogyakarta. Sampel penelitian dengan menggunakan sampel jenuh atau sampel total, karena yang menjadi sampel adalah keseluruhan dari anggota populasi dalam penelitian. Populasi sampel berjumlah 44 orang. 
Tabel 1.Daftar Populasi dan Sampel

\begin{tabular}{clc}
\hline No & Nama SMK & Asesor \\
\hline 1 & SMK N 2 Yogyakarta & 9 \\
2 & SMK N 3 Yogyakarta & 6 \\
3 & SMK N 7 Yogyakarta & 6 \\
4 & SMK Muhammadiyah 1 Yogyakarta & 8 \\
5 & SMK Piri 3 Yogyakarta & 5 \\
6 & SMK Berbudi Yogyakarta & 2 \\
7 & SMK Bopkri Yogyakarta & 4 \\
8 & SMK Ibu Pawiyatan Tamansiswa & 4 \\
\hline Jumlah & 44 orang \\
\hline
\end{tabular}

Pengumpulan data penelitian dilakukan dengan cara menyebar angket (kuesioner). Kuesioner dalam penelitian ini termasuk dalam jenis kuesioner tertutup karena telah disediakan jawaban sehingga responden hanya memilih salah satu alternatif jawaban. Kuesioner pada penelitian ini terbagi kedalam empat aspek yaitu aspek context, input, process, dan product. Langkah yang dilakukan dalam menyusun angket adalah sebagai berikut: (1) menentukan kajian teori yang tepat dan berkaitan dengan penelitian; (2) mencari referensi penelitian yang sudah ada; (3) menggabungkan antara kajian teori yang dipilih dengan referensi penelitian yang sudah ada; (4) menentukan spesifikasi instrumen. Spesifikasi instrumen berisi tujuan pengukuran, kisi-kisi instrumen, memilih bentuk dan format instrument; (5) melakukan penulisan instrument; (6) meminta validasi ahli terhadap instrumen yang telah dikembangkan; (7) memperbaiki instrumen berdasarkan hasil validasi ahli; (8) melakukan ujicoba instrument; (9) menganalisis hasil uji coba untuk mengetahui validitas dan realibilitas; (10) memperbaharui instrumen berdasarkan hasil perhitungan validitas dan realibilitas empiris. Item yang nantinya digunakan pada masing- masing instrumen variabel penelitian hanyalah yang memenuhi syarat valid dan reliabel sesuai dengan hasil validitas isi dan uji coba instrumen.

Untuk memperoleh bukti validitas diperlukan dua jenis validitas yaitu validitas isi (content validity) dan validitas konstruk (construct validity). Untuk memperoleh bukti validitas isi pada instrumen penelitian dilakukan dengan cara meminta pertimbangan ahli (expert judgment). Untuk memperoleh bukti validitas isi pada instrumen penelitian dilakukan dengan cara meminta pertimbangan ahli (expert judgment). Validitas isi instrumen yang berupa angket ini dilakukan oleh 2 (dua) orang ahli yaitu Bapak Prof. Dr. Herminarto Sofyan, M.Pd , selaku ahli dalam bidang pembelajaran pendidikan vokasi dan Bapak Herman Dwi Surjono, Ph.D., selaku ahli dalam multimedia pembelajaran. Berdasarkan penilaian dari kedua ahli tersebut dinyatakan bahwa lembar angket yang digunakan untuk mengumpulkan data penelitian sudah dapat digunakan untuk mengumpulkan data penelitian di lapangan. Validitas konstruk dilakukan dengan uji terbatas pada instrumen penelitian. Selanjutnya instrumen penelitian ini dianalisis butir, yaitu dengan cara mengkorelasikan melalui rumus "Product Moment" dari Pearson. Menurut Sugiyono (2011, p.188), syarat minimum untuk dianggap memenuhi syarat validitas adalah jika $r$ $\geq 0,30$. Harga korelasi butir soal dengan skor total kurang dari 0,30 maka butir soal dalam instrumen tersebut dinyatakan tidak valid begitu pula sebaliknya jika harga korelasi butir soal dengan skor total lebih dari sama dengan 0,30 maka butir soal dalam instrumen tersebut dinyatakan valid atau sahih. Perhitungan analisis validitas instrumen menggunakan bantuan software statistik SPSS versi 17.

Uji coba instrumen dilakukan di SMK SeKabupaten Bantul dan Sleman yang memiliki kompetensi keahlian multimedia dan telah melaksanakan uji kompetensi siswa keahlian, yaitu SMK N 1 Bantul, SMK N 2 Sewon, 
SMK Muhammadiyah 1 Bambanglipuro, SMK Pembangunan Dlingo, SMK N 1 Godean dan SMK Muhammaduyah Sleman. Total jumlah responden uji coba berjumlah 31 orang, yang terdiri dari asesor guru produktif multimedia dan DUDI. Berdasarkan hasil analisis uji coba instrumen, item yang kurang dari 0,30 dari aspek context yaitu item 10, 15, dan 16; aspek input yaitu item 21 ; aspek process yaitu item 4, 8, dan 13, dan aspek product yaitu item 4, 5,6 , dan 8. Semua item dari masing-masing aspek yang harga korelasinya kurang dari 0,30 dinyatakan tidak valid dan item tersebut tidak dipakai dalam instrumen pengumpulan data karena dari item yang tidak valid dari setiap aspek masih ada item valid yang dapat mewakili indikator yang diukur.

Reliabilitas pada instrumen evaluasi uji kompetensi dari segi context, input, process, dan product pada penelitian ini dihitung dengan menggunakan rumus Alpha Cronbach karena instrumen yang digunakan berupa angket dan skalanya bertingkat. Perhitungan reliabilitas instrumen dibantu menggunakan software statistik SPSS versi 17. Klasifikasi kategori koefisien realibilitas $\alpha$ menurut Riduwan (2009: 124) adalah sebagai berikut:

Tabel 2. Interpretasi Nilai Reliabilitas

\begin{tabular}{cc}
\hline Koefisien & Tingkat \\
Reliabilitas & Reliabilitas \\
\hline $0,800-1,000$ & Sangat tinggi \\
$0,600-0,799$ & Tinggi \\
$0,400-0,599$ & Cukup \\
$0,200-0,399$ & Rendah \\
Kurang dari 0,200 & Sangat rendah \\
\hline
\end{tabular}

Berdasarkan hasil uji coba instrumen diketahui hasil reliabilitas instrumen angket dari aspek context yaitu 0,775 (tinggi), aspek input yaitu 0,923 (sangat tinggi), aspek process yaitu 0,843 (sangat tinggi), dan aspek product yaitu 0,792 (tinggi).

Data penelitian yang diperoleh selanjutnya dilakukan coding data \& dianalisa secara deskriptif. Analisis digunakan untuk menghitung mean, median, modus, standar deviasi, tabel distribusi data dan grafik kategori dalam kalimat. Kategori tersebut menurut Djemari (2008: 123) dibagi menjadi empat yaitu:
Tabel 3. Kategori Data Hasil Penelitian

\begin{tabular}{lll}
\hline No & Skor Responden & Kategori \\
\hline 1 & $\mathrm{X} \geq \overline{\mathrm{X}}+1 . \mathrm{SBx}$ & Sangat Tinggi \\
2 & $\overline{\mathrm{X}}+1 . \mathrm{SBx}>\mathrm{X} \geq \overline{\mathrm{X}}$ & Tinggi \\
3 & $\overline{\mathrm{X}}>\mathrm{X}>\overline{\mathrm{X}}-1 . \mathrm{SBx}$ & Rendah \\
4 & $\mathrm{X}<\overline{\mathrm{X}}-1 . \mathrm{SBx}$ & Sangat Rendah \\
\hline
\end{tabular}

Rumus tersebut digunakan untuk mengkategorikan data guru/dudi terkait dengan CIPP uji kompetensi keahlian multimedia. Proses perhitungan prosentase pencapaian dengan menggunakan rumus:

$$
\text { Tingkat Pencapaian }=\frac{\text { Skor Riil }}{\text { Skor Ideal }} \times 100 \%
$$

\section{HASIL PENELITIAN DAN PEMBAHASAN}

Hasil penelitian statistik deskriptif aspek context diperoleh bahwa harga rata-rata (mean) sebesar 44,05; nilai tengah (median) sebesar 43,50; nilai paling banyak diperoleh (mode) sebesar 48,00. Data tersebut memiliki standard deviation (penyimpangan baku) sebesar 5,158; nilai minimum sebesar 52; nilai maksimum sebesar 35; dan nilai skewness 0,009 . Nilai mean lebih dari median, dan median kurang dari modus maka data distribusinya juling positif/ miring ke kanan (skewness positif). Ukuran Skewness adalah 0,009. Untuk penilaian, nilai tersebut diubah ke angka rasio. Rasio skewness adalah $=$ nilai skewness $/$ standard error skewness $=0,009 / 0,357=0,025$. Karena rasio skewness berada antara -2 sampai dengan +2 , maka distribusi data adalah normal.

Evaluasi Uji Kompetensi Siswa Keahlian Multimedia di SMK Se-Kota Yogyakarta ditinjau dari aspek context menunjukkan bahwa uji kompetensi siswa keahlian multimedia di SMK Se-Kota Yogyakarta termasuk dalam kategori sangat sesuai dengan nilai pencapaian kualitas sebesar 44,05 (84,7\%). Indikator yang terdapat pada instrumen ini yaitu: (1) kesesuaian uji kompetensi siswa dengan tujuan dan kebijakan; (2) kesesuaian uji kompetensi siswa dengan tuntutan pengembangan diri dan peluang tamatan multimedia di dunia usaha dan industri; (3) kesesuaian uji kompetensi 
siswa dengan kemajuan IPTEK di bidang multimedia.

Berdasarkan grafik pada Gambar 2, butir pada indikator kebijakan dan tujuan uji kompetensi yang memiliki nilai terendah yaitu senilai 3,36 bahwa tujuan uji kompetensi sebagai penentuan kelulusan peserta didik di sekolah. Nilai tertinggi sebesar 3,61 bahwa uji kompetensi bertujuan untuk menilai pencapaian kompetensi lulusan dan sebagai informasi bagi stakeholder atas kompetensi yang dimiliki calon tenaga kerja. Dari hasil tersebut diketahui bahwa tujuan dan kebijakan dalam uji kompetensi dalam kategori sangat baik, responden menyatakan sangat setuju bahwa uji kompetensi merupakan salah satu upaya untuk meningkatkan mutu pendidikan. Uji kompetensi merupakan suatu upaya untuk menguji kemampuan dan kualitas siswa kompeten atau tidak kompeten terhadap standar kompetensi yang telah ditetapkan.

Pada indikator tuntutan pengembangan diri dan peluang tamatan multimedia di dunia usaha dan indutri, butir yang memiliki nilai kualitas terendah yakni sebesar 2,73 yaitu bahwa kesesuaian uji kompetensi dengan peluang kerja siswa lulusan multimedia dalam skala internasional masih sangat rendah. Menurut responden, uji kompetensi belum bisa mencerminkan kompetensi siswa untuk terjun di industri skala internasional, peluang kerja lulusan multimedia masih hanya di industri skala lokal, bahkan untuk skala nasional pun masih rendah.

Pada indikator kemajuan IPTEK dibidang multimedia, nilai butir yang diperoleh sebesar 3,48 bahwa uji kompetensi sesuai dengan pemanfaatan ICT dalam pendidikan dan 3,57 bahwa uji kompetensi dikembangkan sesuai kemajuan IPTEK di bidang multimedia. Ini berarti bahwa kemajuan IPTEK di bidang multimedia dalam uji kompetensi siswa berusaha diikuti dan dikembangkan agar dapat memenuhi kebutuhan publik dalam dunia kreatif di bidang multimedia.

Berdasarkan uraian di atas, ditinjau dari aspek context bahwa uji kompetensi merupakan suatu upaya untuk meningkatkan mutu pendidikan dan mutlak dilaksanakan untuk siswa SMK sehingga dapat mengungkap ketercapa- ian kompetensi siswa. Uji kompetensi dikembangkan berdasarkan SKL dan SKL harus selalu menyesuaikan KKNI dan perkembangan DUDI sehingga output dari uji kompetensi sesuai dengan kebutuhan DUDI. Sehingga mampu meningkatkan peluang kerja.

Hasil penelitian statistik deskriptif aspek input diperoleh hasil bahwa harga ratarata (mean) sebesar 70,09; nilai tengah (median) sebesar 72 ; nilai paling banyak diperoleh (mode) sebesar 72. Data tersebut memiliki standard deviation (penyimpangan baku) sebesar 5,2; nilai minimum sebesar 56; nilai maksimum sebesar 77; nilai skewness $\neg 1,109$. Nilai mean kurang dari median dan modus maka data distribusinya juling negatif/ miring ke kiri (skewness negatif). Ukuran Skewnes adalah $-1,109$. Untuk penilaian, nilai tersebut diubah ke angka rasio. Rasio skewness adalah $=$ nilai skewness/standard error skewness $=$ $1,109 / 0,357=-3,106$. Karena rasio skewness tidak berada antara -2 sampai dengan +2 , maka distribusi data adalah tidak normal.

Evaluasi Uji Kompetensi Siswa Keahlian Multimedia di SMK Se-Kota Yogyakarta ditinjau dari aspek input menunjukkan bahwa uji kompetensi siswa keahlian multimedia di SMK Se-Kota Yogyakarta termasuk dalam kategori sangat sesuai dengan nilai pencapaian kualitas sebesar 70,09 (87,61\%). Indikator yang terdapat pada instrumen ini yaitu: (1) kesesuaian uji kompetensi siswa dengan kriteria asesor; (2) ketersediaan perangkat uji kompetensi; (3) kelayakan tempat uji kompetensi; dan (4) kelengkapan sarana dan prasarana.

Berdasarkan grafik pada Gambar 3, butir pada indikator kriteria asesor memiliki nilai kualitas terendah yakni sebesar 1,39 yaitu asesor eksternal tidak pernah berasal dari industri berskala internasional, asesor masih sangat dominan berasal dari industri skala lokal. Menurut responden, pentingnya kualitas asesor dalam uji kompetensi menjadikan kriteria asesor harus terus ditingkatkan, bukan hanya skala lokal, namun juga skala nasional bahkan internasional. Dalam uji kompetensi siswa, DUDI sangat berperan penting dalam penilaian kompetensi yang dimiliki siswa, DUDI berfungsi sebagai eksternal yang harus memenuhi kriteria yang telah ditetapkan dan mempunyai 


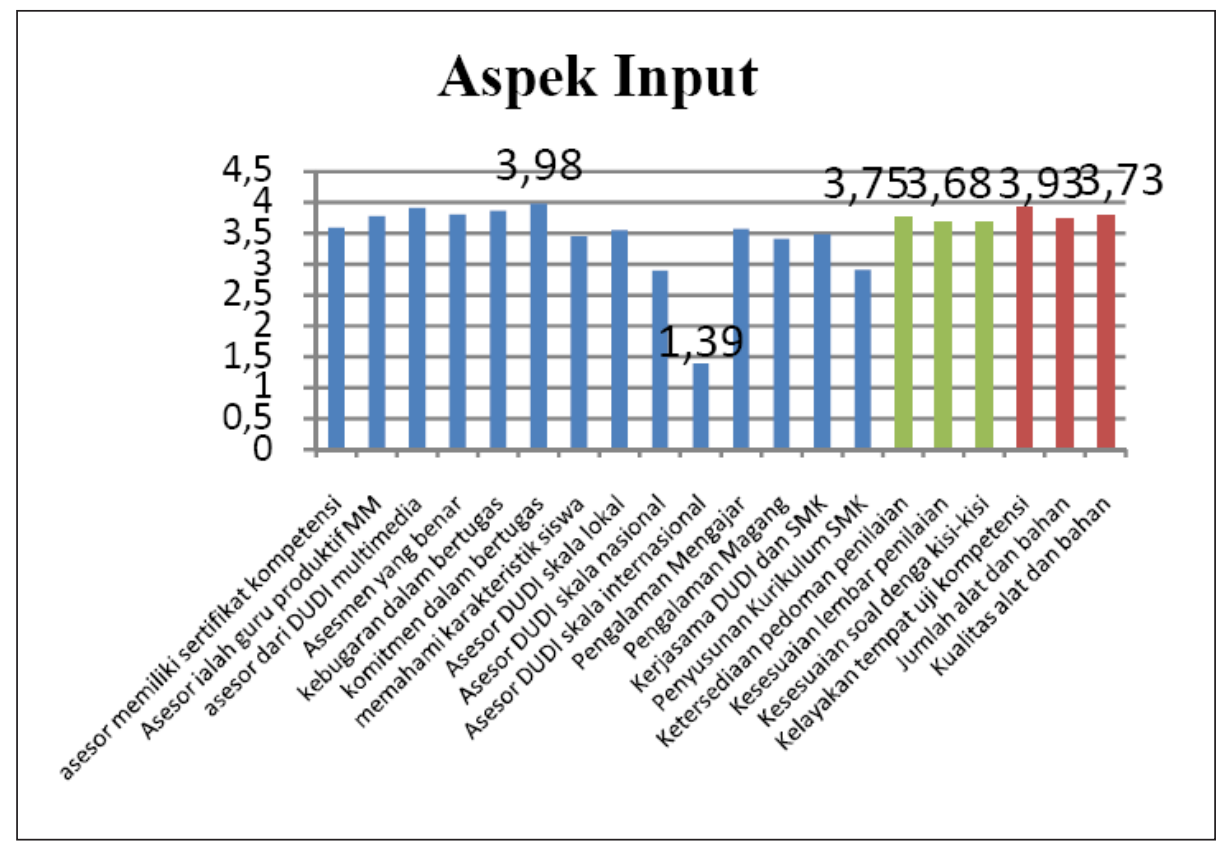

Gambar 3. Grafik Nilai Pencapaian Input

kompetensi sesuai bidang yang diujikan. Butir yang memiliki nilai kualitas paling tinggi dari indikator asesor yakni sebesar 3,98 dan termasuk dalam indikator komitmen asesor dalam bertugas, sehingga dalam uji kompetensi asesor bisa memberikan penilaian dengan benar. Pada indikator ketersediaan perangkat uji kompetensi, nilai pencapaian kualitas butir mengenai lembar pedoman penilaian yaitu sebesar 3,75 dan nilai pencapaian kualitas sebesar 3,68 mengenai kesesuaian pake. Ini berarti bahwa ditinjau dari perangkat uji kompetensi sudah sangat baik, yakni dalam uji kompetensi tersedia lembar penilaian. Namun menurut responden keterbatasan paket soal yaitu belum bisa merepresentasikan SKL keahlian multimedia secara utuh. Pemilihan paket soal dipilih sesuai dengan kondisi sekolah masing-masing. Pada indikator tempat uji kompetesni dan sarana prasarana, butir soal lain yang memiliki nilai kualitas tinggi yakni indikator kelayakan tempat uji kompetensi dengan nilai sebesar 3,93, artinya bahwa dalam uji kompetensi siswa keahlian multimedia di SMK Se-Kota Yogyakarta tempat uji kompetensi dinilai sangat layak, namun dalam hal ini perlu peningkatan kembali pada indikator jumlah dan kualitas alat dan bahan untuk uji kompetensi.

Hasil penelitian statistik deskriptif aspek process diperoleh hasil bahwa harga rata-rata (mean) sebesar 46,77; nilai tengah (median) sebesar 47; nilai paling banyak diperoleh (mode) sebesar 47. Data tersebut memiliki standard deviation (penyimpangan baku) sebesar 3,497; nilai minimum sebesar 34; nilai maksimum sebesar 52; nilai skewness $-1,066$. Nilai mean kurang dari median dan modus maka data distribusinya juling negatif/ miring ke kiri (skewness negatif). Ukuran Skewnes adalah $-1,066$. Untuk penilaian, nilai tersebut diubah ke angka rasio. Rasio skewness adalah $=$ nilai skewness $/$ standard error skewness $=$ $-1,066 / 0,357=-2,986$. Karena rasio skewness tidak berada antara -2 sampai dengan +2 , maka distribusi data adalah tidak normal.

Evaluasi Uji Kompetensi Siswa Keahlian Multimedia di SMK Se-Kota Yogyakarta ditinjau dari aspek process menunjukkan bahwa uji kompetensi siswa keahlian multimedia di SMK Se-Kota Yogyakarta termasuk dalam kategori sangat sesuai dengan nilai pencapaian kualitas sebesar 46,77 (89,94\%). Indikator yang terdapat pada instrumen ini yaitu: (1) kesesuaian uji kompetensi siswa dengan waktu; (2) kesesuaian uji kompetensi siswa dengan prosedur; (3) pengawasan uji kompetensi; dan (4) sistem penilaian.

Berdasarkan grafik pada gambar 4, butir yang memiliki nilai kualitas paling rendah dari 


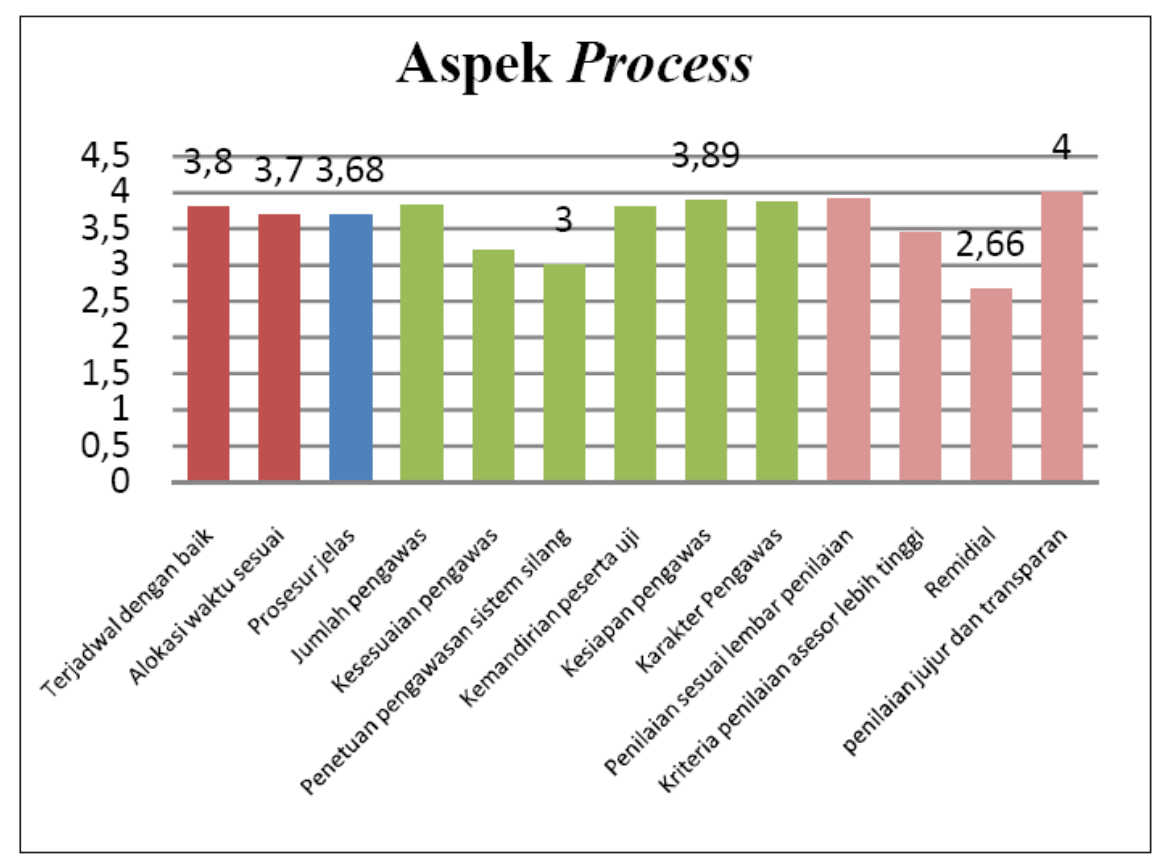

Gambar 4. Grafik Nilai Pencapaian Process

indikator waktu ialah 3,7, bahwa dalam pelaksanaan uji kompetensi telah terjadwal dengan baik namun dari segi alokasi waktu masih kurang, sehingga perlu di tambah untuk hasil yang lebih maksimal. Sementara itu untuk indikator kesesuaian uji kompetensi dengan prosedur sudah sangat jelas dengan nilai pencapaian kualitas sebesar 3,68.

Dalam indikator pengawasan uji kompetensi keahlian NPK terendah sebesar 3,00 bahwa pengawasan tidak ditentukan dengan sistem silang, pengawas berasal dari guru sekolah masing-masing. Kesiapan pengawas dalam uji kompetensi termasuk dalam kategori sangat tinggi dengan NPK sebesar 3,89. Dalam indikator sistem penilaian nilai kualitas paling tinggi yakni sebesar 4,00 bahwa dalam uji kompetensi sistem penilaian jujur dan transparan. Dan untuk NPK terendah yaitu 2,66 yakni dalam uji kompetensi keahlian diperlukan remidial untuk komponen yang belum mencapai standar.

Dari uraian di atas uji kompetensi ditinjau dari aspek process dalam kategori sangat baik, dengan beberapa indikator yang harus diperhatikan, yaitu dalam penetuan alokasi waktu, sistem pengawasan, dan remidial dalam sistem penilaian. Alokasi waktu harus disesuaikan dengan paket soal, berdasarkan hasil penelitian alokasi waktu dalam uji kompetensi keahlian multimedia masih kurang, sehingga peserta uji bahkan asesor mengalami kesulitan. Dalam sistem pengawasan, hambatan pengawas silang adalah kesesuaian dengan kompetensi keahlian. Dalam sistem penilaian, remedial diperlukan dalam uji kompetensi untuk memenuhi kriteria penilaiaan.

Hasil penelitian statistik deskriptif aspek product diperoleh hasil bahwa harga rata-rata (mean) sebesar 33,11; nilai tengah (median) sebesar 32; nilai paling banyak diperoleh (mode) sebesar 31. Data tersebut memiliki standard deviation (penyimpangan baku) sebesar 3,699; nilai minimum sebesar 26; nilai maksimum sebesar 40; nilai skewness 0,556. Nilai mean lebih dari median dan modus maka data distribusinya juling positif/ miring ke kanan (skewness positif). Ukuran Skewnes adalah 0,556 . Untuk penilaian, nilai tersebut diubah ke angka rasio. Rasio skewness adalah $=$ nilai skewness/standard error skewness= $0,556 / 0,357=1,557$. Karena rasio skewness berada antara -2 sampai dengan +2 , maka distribusi data adalah normal.

Evaluasi Uji Kompetensi Siswa Keahlian Multimedia di SMK Se-Kota Yogyakarta ditinjau dari aspek product menunjukkan bahwa uji kompetensi siswa keahlian multimedia di SMK Se-Kota Yogyakarta ditinjau dari aspek 


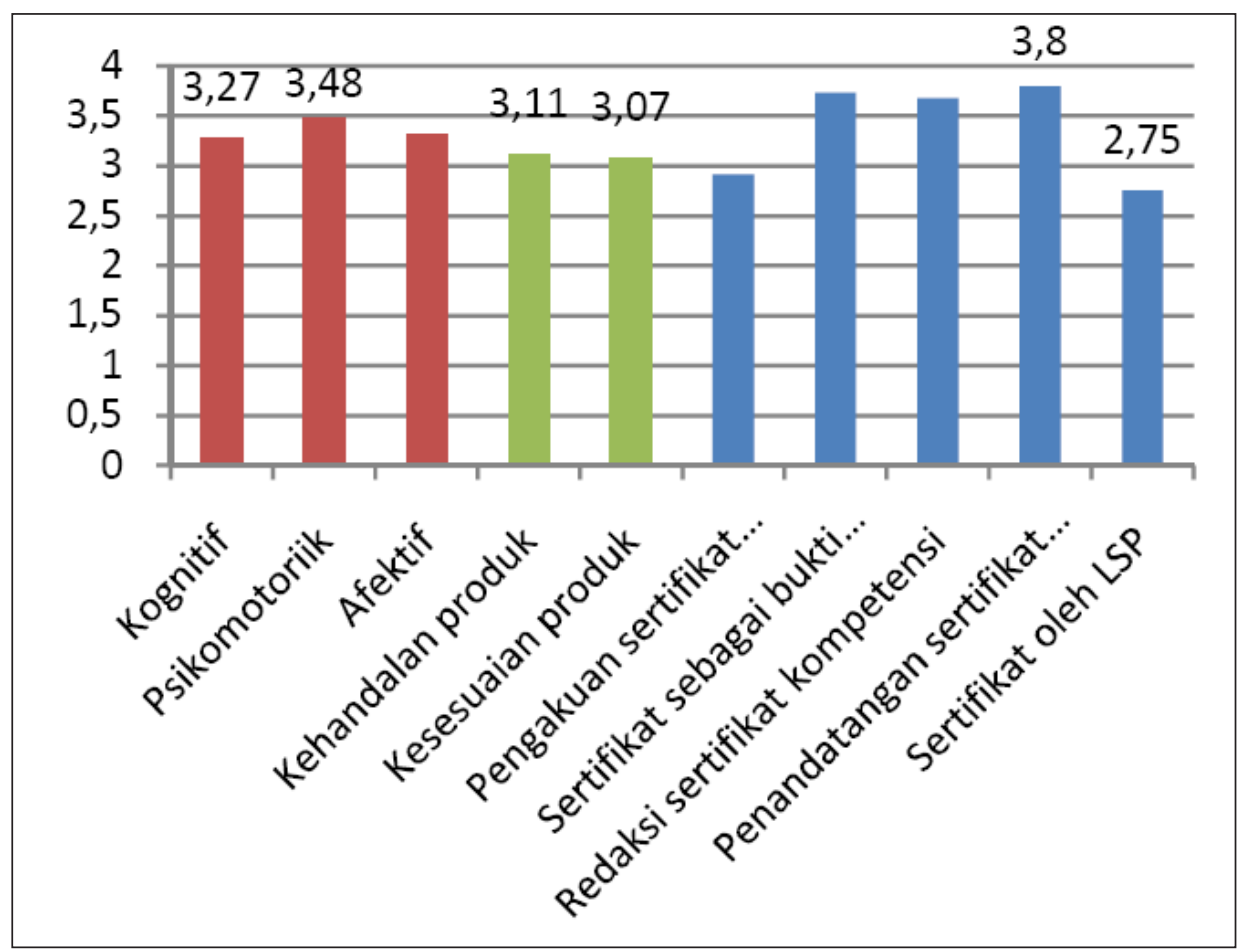

Gambar 5. Grafik Nilai Pencapaian Product

product termasuk dalam kategori sangat tinggi dengan nilai pencapaian kualitas sebesar 33,11 $(82,78 \%)$. Indikator yang terdapat pada instrumen ini yaitu: (1) dokumen hasil uji kompetensi; (2) produk uji kompetensi; dan (3) sertifikat kompetensi.

Berdasarkan grafik pada Gambar 5, butir dari indikator dokumen hasil uji kompetensi yang memiliki nilai kualitas paling rendah adalah dari aspek kognitif yaitu 3,27, dan aspek psikomotorik memiliki nilai yang paling tinggi yaitu sebesar 3,48, ini berarti bahwa aspek kognitif peserta uji harus ditingkatkan agar bisa sesuai dengan kualifikasi lulusan. Butir dari indikator kehandalan produk uji kompetensi memiliki NPK sebesar 3,11 dan kesesuaian produk dengan kebutuhan masyarakat sebesar 3,0. Butir dari indikator sertifikat kompetensi yang terendah adalah 2,75 ini berarti bahwa responden menyatakan setuju dengan adanya uji kompetensi dengan sertifikat dari LSP dan NPK tertinggi yaitu sebesar 3,8 bahwa responden menyatakan sangat setuju sertifikat kompetensi sebagai bukti penguasaan kompetensi siswa dan penandatangan sertifikat kompetensi tersebut dilakukan oleh sekolah dan asesor eksternal.
Ditinjau dari aspek product uji kompetensi harus diperhatikan dalam penguasaan aspek kognitif karena hal tersebut sangat mempengaruhi penilaian akhir terhadap kompetensi siswa. Kehandalan produk uji kompetensi harus disesuaikan dengan kebutuhan dan tuntutan publik, karena dengan uji kompetensi yang berkualitas tinggi/ ideal diharapkan mampu menghasilkan calon-calon tenaga kerja yang berkualitas tinggi pula. Aspek product lainnya yang harus diperhatikan yaitu sertifikat kompetensi peserta uji. Idealnya sertifikat uji kompetensi diterbitkan dan ditandatangani oleh LSP telematika, namun karena persoalan dana maka dalam uji kompetensi siswa keahlian multimedia di SMK Se-Kota Yogyakarta hanya ditandatangani oleh penyelenggara sekolah dan asesor eksternal.

Evaluasi Uji Kompetensi Siswa Keahlian Multimedia di SMK Se-Kota Yogyakarta ditinjau dari aspek context, input, process, product secara akumulatif termasuk kedalam kategori sangat baik dengan nilai pencapaian kualitas sebesar $194,02(86,62 \%)$. Hal yang perlu diperhatikan jika ditinjau dari aspek context yaitu kesesuaian uji kompetensi dengan peluang kerja siswa lulusan multimedia dalam skala 
internasional masih sangat rendah. Hal yang perlu diperhatikan jika ditinjau dari aspek input yaitu pentingnya kualitas asesor dalam uji kompetensi (kriteria asesor). kesesuaian paket soal, dan jumlah dan kualitas alat dan bahan untuk uji kompetensi. Hal yang perlu diperhatikan jika ditinjau dari aspek process yaitu dalam penetuan alokasi waktu, sistem pengawasan, dan remidial dalam sistem penilaian. Hal yang perlu diperhatikan jika ditinjau dari aspek product yaitu dalam penguasaan aspek kognitif, produk uji kompetensi harus disesuaikan dengan kebutuhan dan tuntutan publik, dan pengakuan terhadap sertifikat kompetensi peserta uji.

\section{SIMPULAN DAN SARAN}

\section{Simpulan}

Berdasarkan permasalahan, tujuan penelitian, hasil analisis dan pembahasan yang telah dipaparkan, maka dapat disimpulkan bahwa: (1) Uji Kompetensi Siswa Keahlian Multimedia di SMK Se-Kota Yogyakarta ditinjau dari aspek context termasuk dalam kategori sangat sesuai $(84,7 \%)$, yaitu relevan dengan kebijakan dan tujuan uji kompetensi, tuntutan pengembangan diri (harapan masyarakat) dan peluang tamatan multimedia di dunia usaha dan industri, serta perkembangan IPTEK; (2) Uji Kompetensi Siswa Keahlian Multimedia di SMK Se-Kota Yogyakarta ditinjau dari aspek input termasuk dalam kategori sangat sesuai $(87,61 \%)$, yaitu memenuhi kesesuaian kriteria asesor, kelengkapan perangkat uji kompetensi, kelayakan tempat ujikompetensi, dan kelengkapan sarana prasarana uji kompetensi; (3) Uji Kompetensi Siswa Keahlian Multimedia di SMK Se-Kota Yogyakarta ditinjau dari aspek process termasuk dalam kategori sangat baik (89,94\%), yaitu efektivitas dari segi waktu, prosedur pelaksanaan, pengawasan dan sistem penilaian dalam uji kompetensi; (4) Uji Kompetensi Siswa Keahlian Multimedia di SMK Se-Kota Yogyakarta ditinjau dari aspek product termasuk dalam kategori sangat baik $(82,78 \%)$, yaitu ketercapaian dari segi hasil uji kompetensi siswa (nilai), produk uji kompetensi dan sertifikat kompetensi; (5) Uji kompetensi siswa keahlian multimedia di SMK Se-
Kota Yogyakarta ditinjau dari aspek context, input, process dan product secara akumulatif termasuk dalam kategori sangat baik $(86,62 \%)$.

\section{Saran/Rekomendasi}

Berdasarkan hasil evaluasi pelaksanaan uji kompetensi siswa keahlian multimedia di SMK Se-Kota Yogyakarta, diajukan saran atau rekomendasi sebagai berikut: (1) Asesor yang kompeten di bidang multimedia sangat berpengaruh terhadap pengakuan dunia usaha dan industri, sehingga harus ada monitoring dan seleksi ketat dari penyelenggara karena masih banyak sekolah multimedia mengambil asesor yang kurang kompeten dengan pertimbangan nilai diberikan sangat tinggi tanpa memperhatikan mutu lulusan; (2) Menambah perlengkapan yang menunjang pelaksanaan uji kompetensi, seperti alat-alat yang digunakan dalam produksi multimedia. Melakukan up to date terhadap materi pembelajaran, peralatan dan bahan praktek yang digunakan di laboratorium, guna meningkatkan kompetensi siswa; (3) Meningkatkan peran guru dan DUDI untuk memberikan penjelasan dan bimbingan pelaksanaan uji kompetensi siswa secara komprehensif kepada siswa. Pihak sekolah dalam pelaksanaan uji kompetensi keahlian sebaiknya menyesuaikan pengaturan waktu (alokasi waktu) dengan tuntutan kompetensi di setiap paket soal dan menyesuaikan dengan ketersediaan perangkat di sekolah; (4) Idealnya produk uji kompetensi multimedia harus bersifat marketable (layak jual), sehingga dalam kehandalan produk pelaksanaan uji kompetensi harus bisa menyesuaikam dengan tuntutan dan kebutuhan di masyarakat; (5) Sertifikat kompetensi dari lembaga resmi (LSP telematika) bisa menjadi bukti penguasaan kompetensi peserta uji agar mendapat pengakuan dari dunia kerja dan industri. Persoalan dana untuk dapat memperoleh sertifikat dari LSP telematika agar bisa dialokasikan, dibantu dari APBN atau APBD.

\section{DAFTAR PUSTAKA}

Berry, M.F. (1979). Student competency testing. The High School Journal, Vol. 62, No. 4 (Jan., 1979), pp. 166-172: University of North Carolina Press. Stable URL: http://www.jstor.org/stable/40365755. 
BNSP. (2013). Pedoman penyelenggaraan uji kompetensi keahlian (ukk) smk tahun pelajaran 2012/2013. Jakarta: Direktorat Pembinaan Sekolah Menengah Kejuruan.

Colardyn, D. (2009). The Certification of competencies. In R. Maclean, D. Wilson (eds.), International handbook of education for the changingworld of work, bridging academic and vocational learning (pp.2777-2792). Bonn: Springer.

Conrad, C. F., \& Wilson, R. F. (1985). Academic program review: Institutional approaches, expectations, and controversies. ASHE - ERIC Higher Education Report No. 5. Washington DC: Association for the Study of Higher Education.

Depdiknas. (2003). Undang-Undang RI No.20, Tahun 2003, tentang Sistem Pendidikan Nasional.

Dominique M. A., Frans J. P \& Rob L. M. (2006). Learning Environments Research. The Design of CompetencyBased Performance Assessment In ELearning (P.45-66). Leiden: Springer.

Fitzpatrick, J. L. , Sanders, J. R., \& Worthen, B. R. (2011). Program evaluation alternative approaches and practical guidelines (4th edition). New Jersey: Pearson.

Gangani, N., McLean, G.N., \& Braden, R.A. (2006). A competency-based human resource development strategy. Performance Improvement Quarterly, 19, 1, 127-14. Diambil pada 8 Sepetember 2013, dari http://proquest.umi.com/pqdweb

Haasler, B. and Erpenbeck, J. (2008). Assessing vocational competences. In Rauner, F. \& Maclean, R (Eds.), Handbook of technical and vocational and training research (pp. 766-774). Bremen: Springer.

Kaufman, R. \& Thomas, S. (2009). Evaluation without fear. New York: New Viewpoint
Kuo-Hung Tseng. 2010. Using the context, input, process and product model to assess an engineering curriculum. Journal World Transactions on Engineering and Technology Education. Ohio: WIETE.

Maclean, R. \& Wilson, D . (2009). International handbook of education for the changing world of work, bridging academic and vocational learning. Bonn: Springer.

Mardapi, D. (2008). Teknik penyusunan instrumen dan nontes. Yogyakarta: Mitra Cendikia Offset.

National Center of Educational Statisitics. (2002). Defining and assessing learning: Exploring competencies-based innitiatives. Diambil pada 29 Oktober 2013 dari http://nces.ed.gov/pubs2002/202025.pdf

Rauner, F. \& Maclean, R. (2008). Handbook of technical and vocational and training research. Bremen: Springer.

Robinson, B. 2002. CIPP to approach evaluation. COLLIT Project.

Ruhland, S.K. (2003). Evaluating Tech Prep Education Programs: Implications for Reporting Program and Student Outcomes. Journal of Vocational Education Research, 28(1), pp. 35-57: University of Minnesota.

Stern, B., (2003). Career and workforce development trends:implications for michigan higher education. Michigan: Career Institute for Education and Workforce Development Ferris State University.

Stufflebeam, D.L., Madamand, C.F., \& Kellaghan, T. (2000). Evaluation models. Boston: Kluwer Academic Publishers.

Sudira, P. (2012). Filosofi \& teori pendidikan vokasi dan kejuruan. Yogyakarta: UNY Press.

Sugiyono. (2011). Metode penelitian kuantitatif, kualitatif dan R\&D. Bandung: CV. Alfabeta. 
United Nations Educational, Scientific And Cultural Organization, (2003). The use of icts in technical and vocational education and training, analytical survey. Moscow: UNESCO.

Wagiran. (2011). Classroom assessment: bagian integral proses pembelajaran kejuruan dalam upaya menyiapkan tenaga kerja secara holistik. INVOTEC, Volume VII, No. 2, Agustus 2011: 199 217.
Wardiman,D. (1998). Pengembangan sumber daya manusia melalui SMK. Jakarta: PT. Jayakarta Agung Offset.

Weiss, C.H. (1972). Evaluation research: methode for assessing program effectiveness. New Jersey: Prentice-Hall. 